\title{
Sequential extraction of quercetin-3-0-rhamnoside from Piliostigma thonningii Schum. leaves using microwave technology
}

\author{
Roli Karole Tsatsop Tsague ${ }^{1}$ (1) - Sidonie Beatrice Kenmogne ${ }^{2} \cdot$ Gertrude Eléonore Djiobie Tchienou $^{1} \cdot$ Karine Parra $^{3}$. \\ Martin Benoît Ngassoum ${ }^{1}$
}

Received: 10 April 2020 / Accepted: 9 June 2020 / Published online: 16 June 2020

(c) Springer Nature Switzerland AG 2020

\begin{abstract}
Piliostigma thonningii (Schum.) Milne-Redh. is a plant rich in quercetin-3-O-rhamnoside (quercitrin), a flavonoid involved in the antioxidant and antimicrobial processes. Microwave assisted extraction (MAE) is a method which gives better extraction yield, enhance the quality of extracts while decreasing the extraction time. This effect, a sequential optimization by response surface methodology using a central composite design, help to determine the optimal conditions for obtaining more antioxidant compounds of $P$. thonningii leaves. The response surface curves showed that there was a positive interaction between the extraction time and the solvent concentration on the DPPH scavenging and iron chelating activities of the extracts. The optimal ethanolic extraction parameters for the highest yield of flavonoids were an extraction time of $69 \mathrm{~s}$, an irradiation power of $380 \mathrm{~W}$ and a solid-liquid ratio of $1 / 10(\mathrm{w} / \mathrm{v})$. On the residue, the optimal extraction parameters for simultaneously obtaining the highest flavonoids yield and the highest antioxidant activity were an extraction time of $49 \mathrm{~s}$, an irradiation power of $520 \mathrm{~W}$ and an ethanol concentration of $67 \%(\mathrm{v} / \mathrm{v})$. HPLC analysis has shown the second optimization helped to further maximize the extraction of active compound quercetin-3-Orhamnoside. Electron microscopy of the powders before and after extraction has shown that microwave heating causes cellular damage. Compared to the maceration extraction method, the combined extracts of sequential MAE provide higher antioxidant activities.
\end{abstract}

Keywords Piliostigma thonningii · Quercetin-3-O-rhamnoside · Microwave-assisted extraction · Antioxidant

$\begin{array}{ll}\text { Abbreviations } \\ \text { MAE } & \text { Microwave assisted extraction } \\ \text { HPLC } & \text { High pressure liquid chromatography } \\ \text { TLC } & \text { Thin layer chromatography } \\ \text { UV } & \text { Ultra violet } \\ \text { NMR } & \text { Nuclear magnetic resonance } \\ \text { HMQC } & \text { Heteronuclear multiple quantum correlation } \\ \text { TFC } & \text { Total flavonoids content } \\ \text { CCD } & \text { Central composite design } \\ \text { DPPH } & 1,1 \text {-Diphenyl-2-picrylhydrazyl } \\ \text { ANOVA } & \text { Analysis of variance }\end{array}$

Abbreviations

Roli Karole Tsatsop Tsague, tsatsoproli@gmail.com; Sidonie Beatrice Kenmogne, kenmognesidonie@yahoo.fr; Gertrude Eléonore Djiobie Tchienou, djiobie@yahoo.fr; Karine Parra, karine.parra@univ-montp2.fr; Martin Benoît Ngassoum, ngassoum@yahoo.fr| ${ }^{1}$ Laboratory of Industrial Chemistry and Bioresources, National School of Agro-Industrial Sciences, University of Ngaoundere, P.O. Box 455 Ngaoundere, Cameroon. ${ }^{2}$ Department of Organic Chemistry, Faculty of Sciences, University of Douala, Douala, Cameroon. ${ }^{3}$ Laboratory of Physical Analysis, University of Montpellier, 34095 Montpellier, France.
MSR Mean square of the regression

SEM Scanning electron microscopy

DAD Direct array detector

RSM Response surface methodology

Piliostigma thonningii (Schum.) Milne-Redh is a plant of the family of Caesalpiniaceae. The plant grows up to $8 \mathrm{~m}$ of height with branches. It has large two-lobed simple

\section{Introduction}


leaves without thorns or spines [1]. It is said that this plant has a vast economic importance [2] and possesses edible and chewable leaves which is believed to relieve thirst. It has been reported $P$. thonningii and other species in the genus Piliostigma possess a wide range of uses to mankind ranging from food for human and animals and also a wide range of medicinal benefits [3]. For medicinal uses, treating loose stool in teething children, wound healing, ulcers, stop bleeding, case of inflammations, bacterial infections, stomach pains, fevers $[1,4]$.

Some phytochemical investigations that had been reported on $P$. thonningii, demonstrated that the plant contains a various family of compounds, alkalloids, anthraquinones, flavonoids, glycosides, saponins, sterols and tannins. Some flavonoids have been isolated from this plant, this include quercitin-3-O-rhamnoside (quercitrin). Quercitrin is highly concentrated in Piliostigma leaves [3]. The antioxidant activity of quercetin-3-O-rhamnoside has been demonstrated by Agung et al. [5]. Mutalib et al. [6] has shown the antimicrobial activity of this flavonoid.

Conventional solvent extraction has been used in the last decades for extraction of bioactive compounds from $P$. thonningii leaves. However, many extraction methods with high efficiency developed for phenolic components extraction from plants, include pressurized liquid extraction [7], microwave assisted extraction (MAE) [8], ultrasound assisted extraction (UAE) [9], Soxhlet extraction and heat reflux extraction [10], and supercritical fluid extraction (SFE) [11]. MAE is an extraction method in which solvents containing solid samples material is heated with microwaves energy to facilitated distribution solutes between the solid material and the solvent, hence extraction time is reduced $[12,13]$. From this process, higher extraction rates is observed as well as a better extraction yield [14]. In the mechanism of MAE, the solvents are heated by microwaves directly both in the surrender and inside the plant, it results in a rapid pressure increase within cells material, then the pressure-driven facilitated mass transfer of compounds of interest out from the plant material, causing disruption of the plant tissue with the release of the target compounds into the solvent $[15,16]$.

However, given the factors influencing the process of $M A E$, optimization of the extraction process parameters is necessary to extract the maximum amount of phenolic compounds [8]. Limited information has been published on the use of microwave technology for the sequential extraction of antioxidant compounds from plant materials. Two factors, irradiation power and extraction time influence each other to a great extent [17].

Although many flavonoids had been isolated and characterized from $P$. thonningii leaves, there is no work on the sequential MAE of these flavonoids. Therefore, the objective of this study was to realize successive optimization of sequential MAE of quercetin-3-O-rhamnoside from $P$. thonningii leaves by Response Surface Methodology (RSM). The optimum extraction parameters (extraction time, irradiation power, solvent concentration, and solid-liquid ratio) to maximize flavonoid yields and antioxidant activities are determined and the antioxidant activity of the combined extracts from the successive MAE had been evaluated.

\section{Materials and methods}

\subsection{Materials}

One batch of $5.0 \mathrm{~kg}$ of $P$. thonningii leaves was collected in Ngaoundere locality, North of Cameroon. The harvested plant was identified by Professor Mapongmetsem, botanist and lecturer in the Department of Biological Sciences, Faculty of Science at the University of Ngaoundere. The collected sample was saved to voucher number 32129/ HNC.

These leaves were air dried for $24 \mathrm{~h}$ and milled. The powder obtained was stored in a sealed container for later use.

All other chemicals (analytical grade) and HPLC solvents (HPLC grade) used in the experiment were purchased from VWR International.

\subsection{Isolation and identification of quercetin-3-0-rhamnoside}

The extracts of $P$. thonningii leaves were obtained by maceration in solvents ( $n$-hexane, ethyl acetate, acetone and methanol respectively) for $4 \mathrm{~h}$ and with mechanical stirring. For this, in an extractor of capacity of $8 \mathrm{~L}, 1.0 \mathrm{~kg}$ of powder of plant powder was mechanically macerated with $2 \mathrm{~L}$ of respective solvent, a metal rod driven in rotation by a motor (DEREIX S. A. PARIS). After $4 \mathrm{~h}$ of maceration, the mixture has been left to stand for 15 min for decantation and then filtered. The filtrate was concentrated using a rotary evaporator under reduced pressure (LaboratiriumsTechnik AG CH-9230 Flawil/Schweiz, Switzerland). For the same solvent, the extraction was repeated three times.

The acetone extract $(40 \mathrm{~g})$ was separated by chromatography on a 605 silica gel column ( $240 \mathrm{~g}, 230-400$ mesh) with the hexane-ethyl acetate and ethyl acetate-methanol systems by gradient of increasing polarity. Fifteen fractions (A-O) were collected on the basis of thin layer chromatography (TLC) analysis. The $C$ fractions (91-104), eluted with hexane-ethyl acetate $(70: 30, \mathrm{v} / \mathrm{v})$, has given a precipitate of yellow crystals $\left(\mathrm{PA}_{4}\right)(1.8 \mathrm{~g})$ representing respectively $4.5 \%$ and $0.18 \%$ of the acetone extract mass and dry plant powder (w/w), respectively. 
The Ultra Violet (UV) spectrum of the compound $\mathrm{PA}_{4}$ resulting from the analysis by HPLC (High Pressure Liquid Chromatography) has maxima at 212; 256 and 350 $\mathrm{nm}$, characteristics of a flavonol. Analysis of the ${ }^{1} \mathrm{H}-\mathrm{NMR}$ (Nuclear Magnetic Resonance) spectrum, carried out in methanol indicates the presence of three signals of the chemical shift (ppm) of aromatic protons at $7.35(\mathrm{~d}, \mathrm{~J}=2.1$ $\left.\mathrm{Hz}, \mathrm{H}-2^{\prime}\right), 6.92\left(\mathrm{~d}, \mathrm{~J}=8.26 \mathrm{~Hz}, \mathrm{H}-5^{\prime}\right)$ and $7.32(\mathrm{dd}, \mathrm{J}=2.3$ and $8.2 \mathrm{~Hz}, \mathrm{H}-6^{\prime}$ ) in the form of an $A B X$ spin system suggesting a flavonol with the $3^{\prime}, 4^{\prime}$-disubstituted positions of $B$ nucleus. It is also observed a pair of meta-coupling proton signals at $6.21(\mathrm{~d}, \mathrm{~J}=2.1 \mathrm{~Hz}, \mathrm{H}-6)$ and $6.38(\mathrm{~d}, \mathrm{~J}=2.1 \mathrm{~Hz}, \mathrm{H}-8)$ corresponding to ring $\mathrm{A}$ (Table 1 ). There are also signals for the osidic fraction, with a signal at $\delta 5.37 \mathrm{ppm}(\mathrm{d}, \mathrm{J}=1.4$ $\mathrm{Hz}, \mathrm{H}-\mathrm{1}^{\prime \prime}$ ) indicating that the compound has bound sugar. The evaluation of the anomeric coupling constant and by comparison with the data in the literature the osidic part can be attributed to rhamnose.

The ${ }^{13} \mathrm{C}$ NMR spectrum supports this hypothesis and shows 21 signals including the carbonyl signal at $\delta 178.5$ ppm (C-4). It revealed chemical shifts (ppm) at $\delta 134.8$ (C-3), 161.8 (C-5), 164.6 (C-7), 148.50 (C-3'), 145.0 (C-4') which suggests an oxygenated flavone nucleus in position $3,5,7,3^{\prime}$ and $4^{\prime}$. This spectrum also shows significant signals of an osidic part at $\delta 102.5(C-1 "), 70.5\left(C-2^{\prime \prime}\right), 70.72$
$\left(C-3^{\prime \prime}\right), 71.87\left(C-4^{\prime \prime}\right), 70.65\left(C-5^{\prime}\right), 16.3\left(C-6^{\prime \prime}\right)$. The chemical displacement of 16.3 (C-6") compared to that of the literature is characteristic of $\mathrm{CH}_{3}$ in rhamnose (Table 1).

Analysis of the HMQC (Heteronuclear Multiple Quantum Correlation) spectrum of the aglycone shows that the $\mathrm{H}$ protons of the carbons $\mathrm{C} 6, \mathrm{C} 8, \mathrm{C5}^{\prime}, \mathrm{C2}{ }^{\prime}, \mathrm{C} 6^{\prime}$, are not substituted since a correlation between $\mathrm{C} 6-\mathrm{H} 6, \mathrm{C} 8-\mathrm{H} 8, \mathrm{C}^{\prime}-\mathrm{H} 5^{\prime}$, $\mathrm{C} 2^{\prime}-\mathrm{H} 2^{\prime}$, and $\mathrm{C}^{\prime}-\mathrm{H} 6^{\prime}$ is observed. Therefore, the structure was determined to be quercetin-3-O-a-rhamnopyranoside (quercitrin) (Fig. 1) previously obtained from the leaves of the same plant by lbewuike et al. [3].

\subsection{Microwave assisted extraction}

The process of MAE was performed with a microwave oven (Daewoo, KOG-360, Combi Grill, Ahyeon-Dong MapoGu Seoul, Korea) with cavity dimensions $(\mathrm{W} \times \mathrm{H} \times \mathrm{D})$ of $290 \times 290 \times 220 \mathrm{~mm}$.

Successive extraction process of quercetin-3-O-rhamnoside compounds from $P$. thonningii leaves powders (previously defatted) was carried out in a sealed vessel of $150 \mathrm{~mL}$ of capacity using ethanol and aqueous ethanol solvents, respectively. First optimization was consisted to use ethanol as solvent to find first optimum conditions of extraction. For this purpose, a study was carried
Table $1{ }^{1} \mathrm{H}$ and ${ }^{13} \mathrm{C}$ NMR spectral data of $\mathrm{PA}_{4}$

\begin{tabular}{|c|c|c|c|c|c|}
\hline \multirow{2}{*}{$\begin{array}{l}\mathrm{C} / \mathrm{H} \\
1\end{array}$} & \multicolumn{2}{|l|}{$\delta \mathrm{H}(\mathrm{ppm}), \mathrm{J}(\mathrm{Hz})$} & \multicolumn{2}{|c|}{$\delta \subset(\mathrm{ppm})$} & \multirow[t]{2}{*}{ HMQC } \\
\hline & $\mathrm{PA}_{4}$ & Quercetin-O-rhamnopyranoside & $\mathrm{PA}_{4}$ & $\begin{array}{l}\text { Quercetin- } \\
\text { O-rhamnopyra- } \\
\text { noside }\end{array}$ & \\
\hline 2 & - & - & 157.5 & 158.6 & - \\
\hline 3 & - & - & 134.8 & 136.3 & - \\
\hline 4 & - & - & 178.5 & 179.7 & - \\
\hline 5 & $12.51(\mathrm{~s}-\mathrm{OH})$ & - & 161.8 & 163.3 & - \\
\hline 6 & $6.21(\mathrm{~d}, \mathrm{~J}=2.1)$ & $6.20(\mathrm{~d}, \mathrm{~J}=2.1)$ & 98.8 & 99.9 & $\mathrm{C}-\mathrm{H}$ \\
\hline 7 & - & & 164.6 & 165.9 & - \\
\hline 8 & $6.38(d, J=2.1)$ & $6.36(d, J=2.2)$ & 93.31 & 94.8 & $\mathrm{C}-\mathrm{H}$ \\
\hline 9 & - & - & 158.1 & 159.4 & - \\
\hline 10 & - & - & 104.5 & 106.0 & - \\
\hline $1^{\prime}$ & - & - & 121.56 & 123.1 & - \\
\hline $2^{\prime}$ & $7.35(d, J=2.1)$ & $7.34(\mathrm{~d}, \mathrm{~J}=2.1)$ & 115.54 & 117.1 & $\mathrm{C}-\mathrm{H}$ \\
\hline $3^{\prime}$ & - & - & 148.5 & 149.9 & - \\
\hline $4^{\prime}$ & - & - & 145.0 & 146.5 & - \\
\hline $5^{\prime}$ & $6.92(d, J=8.26)$ & $6.92(\mathrm{~d}, \mathrm{~J}=8.3)$ & 114.98 & 116.5 & $\mathrm{C}-\mathrm{H}$ \\
\hline $6^{\prime}$ & $7.32(\mathrm{dd}, J=8.2$ and 2.90$)$ & $7.31(\mathrm{dd}, \mathrm{J}=8.3$ and 2.1$)$ & 121.4 & 122.0 & $\mathrm{C}-\mathrm{H}$ \\
\hline $1 "$ & $5.37(d, J=1.34)$ & $5.35(d, J=1.6)$ & 102.5 & 103.6 & $\mathrm{C}-\mathrm{H}$ \\
\hline $2^{\prime \prime}$ & $4.24(\mathrm{dd}, J=3.2$ and 1.73$)$ & $4.23(\mathrm{dd}, \mathrm{J}=3.3$ and 1.7$)$ & 70.5 & 72.0 & - \\
\hline $3 "$ & $3.77(\mathrm{dd}, \mathrm{J}=9.72$ and 3.32$)$ & $3.77(\mathrm{dd}, \mathrm{J}=9.4$ and 3.4$)$ & 70.72 & 72.3 & - \\
\hline $4^{\prime \prime}$ & - & $3.36(t, J=9.5)$ & 71.87 & 73.4 & - \\
\hline $5^{\prime \prime}$ & - & $3.44(\mathrm{dd}, J=9.6$ and 6.1$)$ & 70.65 & 72.1 & - \\
\hline $6^{\prime \prime}$ & $0.96(d, J=6.07)$ & $0.95(d, J=6.2)$ & 16.3 & 17.7 & $\mathrm{C}-\mathrm{H}$ \\
\hline
\end{tabular}


out beforehand to choose and define the experimental domains of the three (3) factors (extraction time, irradiation power and solid-liquid ratio) (Table 2). Subsequently, a central composite design (CCD) on 18 experiments was used to determine the optimal levels of these three factors influencing this extraction as well as the study of interactions between these different factors. The response followed during the extraction was the total flavonoids content (TFC). The determination of the TFC was performed on the filtrates obtained after extraction at different extraction conditions. Four replicates were performed in each extraction.

Secondly, at the optimum condition previously found, the extraction was carried out and the residue resulting from this ethanolic extraction was air dried in laboratory. This residue was then used like our plant material for extraction using aqueous ethanol like solvent to optimize the yield of flavonoids and antioxidant activity. Modeling using the RSM approach was used. Thus, a second CCD was used to determine the optimal levels of three factors (extraction time, irradiation power, solvent concentration) influencing this extraction (Table 3 ). The responses followed during the extraction are the total flavonoids contents (TFC), the free-radical DPPH scavenging activity $\left(\% \mathrm{DPPH}_{\text {scavenging }}\right)$ and ferrous ion chelating activity (\% Iron $\left._{\text {chelation }}\right)$. These analyzes were carried out on the filtrates obtained after extraction under different extraction conditions. In each extraction, four replicates had been performed.

\subsection{Determination of total flavonoids content (TFC)}

Total flavonoids content (TFC) were evaluated as described by Cornard and Merlin method, with slight modifications. This method is based on the oxidation of flavonoids by aluminum chloride. It results in the formation of a brownish complex that absorbs at $415 \mathrm{~nm}$ [18]. For experiment,
$1 \mathrm{~mL}$ of methanolic solution of $\mathrm{AlCl}_{3}(2 \%, \mathrm{w} / \mathrm{v})$ was mixed with $20 \mu \mathrm{L}$ of solution of the different extracts. After 20 min at room temperature in dark, the absorbance was read at $415 \mathrm{~nm}$ with the spectrophotometer (Spectrophotometer UV-6300PC, 634-0776, VWR International) against the blank $(0.5 \mathrm{~mL}$ of methanolic solution of aluminum chloride ( $2 \%(\mathrm{w} / \mathrm{v})$ and $1 \mathrm{~mL}$ of methanol). Using these absorbances of extracts, the standard curve of quercitrin (Absorbance $=20.325 \mathrm{QE}, \mathrm{R}^{2}=0.98$ with $\mathrm{QE}$ in $\mathrm{mg}$ ) was used to determine the mass of quercitrin extracted. In this study, the results were expressed in $\mathrm{mg}$ of quercitrin equivalent (QE) per gram of material (mg QE/g).

\subsection{Antioxidant activity}

\subsubsection{Determination of DPPH free-radical scavenging activity (\%DPPHsc)}

The 1,1-diphenyl-2-picrylhydrazyl (DPPH) free radicalscavenging activity of the extracts (pre-diluted at a ratio of 1:100) was evaluated using Dahmoune et al. [13] method. For this study, aliquots of different extracts $(10 \mu \mathrm{L})$ were added to $500 \mu \mathrm{L}$ of methanolic solution fo DPPH $(70 \mu \mathrm{M})$. The mixture obtained was incubated for $20 \mathrm{~min}$ at $37^{\circ} \mathrm{C}$ in the dark. The decrease in absorbance of the mixture was measured at $517 \mathrm{~nm}$. The DPPH free-radical scavenging activity (\%) was calculated using the equation:

$\% \mathrm{DPPH}_{\text {scavenging }}=\frac{\left(A_{O}-A_{F}\right) \times 100}{A_{O}}$

where $A_{O}$ was defined as the absorbance before addition of extract, whereas $A_{F}$ was defined as absorbance value after 20 min of incubation time.
Table 2 Experimental factors level table of central composite design (CCD) for ethanolic optimization

\begin{tabular}{lllllll}
\hline Factors (units) & \multicolumn{2}{l}{ Range and levels } \\
\cline { 2 - 7 } & Notation & -1.414 & -1 & 0 & 1 & 1.414 \\
\hline Extraction time $(\mathrm{s})$ & $\mathrm{X}_{1}$ & 56 & 60 & 70 & 80 & 84 \\
Irradiation power $(\mathrm{W})$ & $\mathrm{X}_{2}$ & 360 & 400 & 500 & 600 & 640 \\
Solid-liquid ratio $(\mathrm{g} / 20 \mathrm{~mL})$ & $\mathrm{X}_{3}$ & 0.8 & 1 & 1.5 & 2 & 2.2 \\
\hline
\end{tabular}

Table 3 Experimental factors level table of central composite design (CCD) for hydroethanolic optimization

\begin{tabular}{llrrrrr}
\hline Factors (units) & \multicolumn{7}{l}{ Range and levels } \\
\cline { 2 - 6 } & Notation & -1.414 & -1 & 0 & 1 & 1.414 \\
\hline Extraction time (s) & $\mathrm{X}_{1}$ & 38 & 40 & 45 & 50 & 52 \\
Irradiation power (W) & $\mathrm{X}_{2}$ & 360 & 400 & 500 & 600 & 640 \\
Solvent concentration (\%) & $\mathrm{X}_{4}$ & 16 & 20 & 30 & 40 & 44 \\
\hline
\end{tabular}




\subsubsection{Measurement of ferrous ion chelating activity}

The iron-chelating abilities of the different extracts was estimated by the slightly modified method of Dinis et al. [19]. $0.05 \mathrm{~mL}$ of different extracts was added to a $2.7 \mathrm{~mL}$ phosphate buffer $(\mathrm{pH}=7.2)$. Then, $0.05 \mathrm{~mL}$ of $\mathrm{FeCl}_{2}(2 \mathrm{mM})$ were added. At $30 \mathrm{~s}$, the reaction was initiated by the addition of $0.2 \mathrm{~mL}$ ferrozine $(5 \mathrm{mM})$, the mixture was shaken vigourously at Vortex for $10 \mathrm{~s}$. After 1 min beyond addition of $\mathrm{FeCl}_{2}$ solution, absorbance of the solution was measured at $562 \mathrm{~nm}$. The ability of extracts to chelate ferrous ion was calculated relative to the control (consisting of phosphate buffer, iron and ferrozine only) using equation:

\% Iron $_{\text {chelation }}=\frac{\left(A_{c}-A_{E}\right) \times 100}{A_{c}}$

where $A_{C}$ is the absorbance of the control, and $A_{E}$ is the absorbance of the extract.

\subsection{Experimental design}

The extraction parameters were optimized using response surface methodology. A central composite design (CCD) was employed in this regard. Irradiation time $\left(X_{1}\right)$, irradiation power $\left(X_{2}\right)$, solid-liquid ratio $\left(X_{3}\right)$ and solvent concentration $\left(X_{4}\right)$ were chosen for independent variables. The range and centre point values of four independent variables, presented in Tables 1 and 2 were based on the results of preliminary experiments. The experimental design in the two case of optimization consists of eight factorial points, six axial points at a distance of \pm 1.414 from the centre and four replicates of the central point. TFC was selected as the responses for the combination of the independent variables given in Table 1, and TFC, $\% \mathrm{DPPH}_{\text {scavenging }}$ and \% Iron $_{\text {chelation }}$ the responses for the combination of the independent variables given in Table 2 . Four experiments were carried out at each experimental design point and the mean values were stated as observed responses. Experimental runs were randomized, to minimize the effects of unexpected variability in the observed responses.

The variables were coded according to the equation:

$x=\frac{(X i-X o)}{X}$

where $\mathrm{X}$ is the coded value, $\mathrm{Xi}$ is the corresponding actual value, $X_{0}$ is the actual value in the centre of the domain and $\Delta \mathrm{X}$ is the increment of $\mathrm{Xi}$ corresponding to a variation of 1 unit of $X$.

The mathematical model corresponding to the composite design is:
$Y_{i}=\beta_{0}+\sum \beta_{i} x_{i}+\sum \beta_{i i} x_{i}^{2}+\sum \beta_{i j} x_{i} x_{j}+\varepsilon$

where $Y_{i}$ is the dependent variables $\left(\right.$ TFC, $\% D$ PPH $H_{\text {scavenging }}$ and $\%\left(\right.$ rron $\left._{\text {chelation }}\right), \beta_{0}$ is the model constant, $\beta_{\mathrm{i}}, \beta_{\mathrm{ii}}$ and $\beta_{\mathrm{ij}}$ are the model coefficients, and $\varepsilon$ is the error. They represent the linear, quadratic and interaction effects of the variables. Analysis of the experimental design data and calculation of predicted responses were carried out using Statgraphics centurion software (Version XVI.I). Additional confirmation experiments were subsequently conducted to verify the validity of the statistical experimental design.

\subsection{Statistical analysis}

Analysis of variance (ANOVA) was used to determine the influence of each factor and the significance of their effects. It then examines the statistical significance of each effect by comparing the squared average against an evaluation of the experimental error. The significance of each factor is determined by the Fisher test which is defined as the ratio of the mean square of the regression (MSR) to the experimental error $(E E)(F=M S R / E E)$, representation of the significance of each variable controlled on the model examined. The regression equations were also subjected to the Fisher test to determine the coefficient of determination $\mathrm{R}^{2}$.

The optimal extraction conditions were estimated through regression analysis and three-dimensional (3D) response surface plots and contour plots (obtained using Sigmaplot 12.0 software) of the independent variables and each dependent variable.

\subsection{HPLC characterization of isolated quercetin-3-0-rhamnoside and extracts at optimum conditions}

The HPLC method used for monitoring quercetin in the various optimized extracts was carried out as follows. Two mobile phases, solvent $\mathrm{A}\left(\mathrm{MeOH}: \mathrm{H}_{2} \mathrm{O}, 80 / 20\right.$, v/v) with $1 \%$ phosphoric acid $(\mathrm{v} / \mathrm{v})$ and solvent $\mathrm{B}(\mathrm{MeOH})$ were used. The elution gradient of the mobile phases $(A: B, v / v)$ was programmed as 60:40 to $0 \mathrm{~min} ; 30: 70$ to $10 \mathrm{~min}$ (constant for $5 \mathrm{~min}$ ); $20: 80$ to $15 \mathrm{~min}$ (constant for $4 \mathrm{~min}$ ); 10:90 to $20 \mathrm{~min}$ (constant for $6 \mathrm{~min}$ ); 0:100 to $25 \mathrm{~min}$ (constant for $6 \mathrm{~min}$ ); 100:0 to $35 \mathrm{~min}$ (constant for $5 \mathrm{~min}$ ). The flow rate and the temperature of the column were kept constant $1 \mathrm{~mL} / \mathrm{min}$ and $40{ }^{\circ} \mathrm{C}$, respectively. The analysis system consists of a DAD (Direct Array Detector) type detector. The detection wavelength was between 190 and $360 \mathrm{~nm}$ for an analysis time of $40 \mathrm{~min}$ per sample. The stock solution of the extracts $(1.0 \mathrm{~g} / \mathrm{mL})$ was prepared by dissolving each extract in its respective solvent. The standard stock 
solution $(0.1 \mathrm{~g} / \mathrm{mL})$ was prepared by dissolving quercetin-3-O-rhamnoside in $\mathrm{MeOH}$. Injection volume of the investigated samples was $20 \mu \mathrm{L}$.

\subsection{Scanning electron microscopy (SEM) analyses}

Powder of $P$. thonningii leaves was observed under SEM (Hitachi S4800, with voltage of 0.1-30 kV) for morphological characterization before and after the extraction processes. Three samples of the powders (untreated, dried residues of MAE and dried residues of successive MAE) were used for SEM analysis. All samples were dried at 70 ${ }^{\circ} \mathrm{C}$ during $1 \mathrm{~h}$ for preparing samples for SEM analysis. Dried sample particles were fixed on a specific support, then metallized by applying a layer of palladium on the sample surface, and their shape and surface characteristics were observed by using gaseous secondary electron detector.

\section{Results and discussion}

\subsection{Optimization of MAE conditions of $P$. thonningii flavonoids with ethanol}

\subsubsection{Modeling and fitting the model with response surface methodology (RSM)}

From a CCD of 18 experiments, the influence of the extraction time $\left(X_{1}\right)$, the irradiation power $\left(X_{2}\right)$ and the solid-liquid ratio $\left(X_{3}\right)$ on the ethanolic extraction of flavonoids from $P$. thonningii by MAE was evaluated. The experimental design and corresponding response data for the total flavonoids content from $P$. thonningii leaves are presented in Table 4. As described by Zhang et al. [20], regression coefficients, linear, quadratic and interaction coefficients of the model were calculated using the least square technique (Table 5).

It was shown that all linear parameters extraction time $\left(X_{1}\right)$, irradiation power $\left(X_{2}\right)$ and solid-liquid ratio $\left(X_{3}\right)$, two interactions $\left(X_{1} X_{3}\right.$ and $\left.X_{2} X_{3}\right)$ and quadratic effect of solid-liquid ratio $\left(X_{3}^{2}\right)$ were highly significant at the level of $p<0.05$ (Table 5) on the ethanolic extraction of flavonoids assisted by microwaves. Considering the significant
Table 4 Central composite design (CCD) and responses of ethanolic MAE of flavonoids from $P$. thonningii leaves

\begin{tabular}{|c|c|c|c|c|c|c|}
\hline \multirow[t]{3}{*}{ Run } & \multicolumn{3}{|c|}{ Actual values } & \multirow{2}{*}{$\begin{array}{l}\text { Experimental } \\
\text { responses } \\
\text { Total } \\
\text { flavonoids } \\
\text { content (mg } \\
\text { QE/g) }\end{array}$} & \multirow{2}{*}{$\begin{array}{l}\text { Calculated responses } \\
\text { Total flavonoids con- } \\
\text { tent (mg QE/g) }\end{array}$} & \multirow[t]{3}{*}{ Residual (\%) } \\
\hline & $\begin{array}{l}\text { Extraction } \\
\text { time }(s)\end{array}$ & $\begin{array}{l}\text { Irradiation } \\
\text { power (w) }\end{array}$ & $\begin{array}{l}\text { Solid-liquid } \\
\text { ratio }(\mathrm{g} / 20 \mathrm{~mL})\end{array}$ & & & \\
\hline & $\mathrm{X}_{1}$ & $x_{2}$ & $x_{3}$ & $\mathrm{Y}_{\mathrm{TFC}}$ & $\mathrm{Y}_{\mathrm{TFC}}$ & \\
\hline 1 & 84 & 500 & 1.5 & 10.73 & 10.76 & 0.26 \\
\hline 2 & 70 & 500 & 2.2 & 10.52 & 10.49 & 0.29 \\
\hline 3 & 70 & 500 & 1.5 & 10.92 & 10.99 & 0.67 \\
\hline 4 & 80 & 400 & 1 & 9.51 & 9.53 & 0.28 \\
\hline 5 & 60 & 600 & 2 & 9.51 & 9.46 & 0.50 \\
\hline 6 & 56 & 500 & 1.5 & 10.15 & 10.17 & 0.16 \\
\hline 7 & 70 & 500 & 1.5 & 11.36 & 10.99 & 3.24 \\
\hline 8 & 60 & 400 & 2 & 11.14 & 11.21 & 0.62 \\
\hline 9 & 70 & 500 & 1.5 & 10.82 & 10.99 & 1.64 \\
\hline 10 & 70 & 641 & 1.5 & 9.67 & 9.71 & 0.28 \\
\hline 11 & 70 & 500 & 1.5 & 10.92 & 10.99 & 0.67 \\
\hline 12 & 70 & 500 & 0.8 & 9.00 & 9.09 & 0.83 \\
\hline 13 & 80 & 400 & 2 & 11.17 & 11.12 & 0.43 \\
\hline 14 & 80 & 600 & 2 & 8.96 & 9.02 & 0.67 \\
\hline 15 & 60 & 400 & 1 & 8.34 & 8.25 & 0.98 \\
\hline 16 & 60 & 600 & 1 & 10.73 & 10.76 & 0.30 \\
\hline 17 & 80 & 600 & 1 & 10.52 & 10.49 & 0.89 \\
\hline 18 & 70 & 358 & 1.5 & 10.92 & 10.99 & 0.15 \\
\hline
\end{tabular}


Table 5 Estimated regression coefficients for the quadratic polynomial model and the analysis of variance (ANOVA) for the experimental results of first extraction of flavonoids from $P$. thonningii leaves

\begin{tabular}{llllll}
\hline Parameters & $\begin{array}{l}\text { Estimated } \\
\text { coeffi- } \\
\text { cients }\end{array}$ & $\begin{array}{l}\text { Degree } \\
\text { of free- } \\
\text { dom }\end{array}$ & $\begin{array}{l}\text { Sum of } \\
\text { squares }\end{array}$ & Fvalue & $P$ value \\
\hline $\mathrm{X}_{1}$ & 0.540 & 1 & 0.529 & 8.93 & 0.0582 \\
$\mathrm{X}_{2}$ & 0.063 & 1 & 1.297 & 22.00 & $\mathbf{0 . 0 1 8 3}$ \\
$\mathrm{X}_{3}$ & 19.498 & 1 & 2.988 & 50.81 & $\mathbf{0 . 0 0 5 7}$ \\
$\mathrm{X}_{1}^{2}$ & -0.003 & 1 & 0.550 & 9.63 & 0.0532 \\
$\mathrm{X}_{1} \mathrm{X}_{2}$ & 0.000 & 1 & 0.061 & 1.04 & 0.3833 \\
$\mathrm{X}_{1} \mathrm{X}_{3}$ & -0.069 & 1 & 0.938 & 16.01 & $\mathbf{0 . 0 2 8 0}$ \\
$\mathrm{X}_{2}^{2}$ & 0.000 & 1 & 1.354 & 23.31 & $\mathbf{0 . 0 1 6 9}$ \\
$\mathrm{X}_{2} \mathrm{X}_{3}$ & -0.013 & 1 & 3.226 & 54.54 & $\mathbf{0 . 0 0 5 1}$ \\
$\mathrm{X}_{3}^{2}$ & -2.451 & 1 & 2.923 & 50.21 & $\mathbf{0 . 0 0 5 8}$ \\
Lack of fit & - & 5 & 0.045 & 0.13 & 0.9744 \\
Pure error & - & 3 & 0.175 & - & - \\
$\mathrm{R}^{2}$ & 0.985 & - & - & - & - \\
Adjusted $\mathrm{R}^{2}$ & 0.967 & - & - & - & - \\
CV (\%) & 1.90 & & & & - \\
Corr. total & & 17 & 14.147 & - & - \\
\hline
\end{tabular}

Bold values indicate the corresponding independent variables are significant on the response

parameters only, the final predictive equation was as follows:

$$
\begin{aligned}
Y_{\text {TFC }}= & -38.93+0.54 X_{1}+0.063 X_{2}+19.50 X_{3} \\
& -0.069 X_{1} X_{3}-0.013 X_{2} X_{3}-2.45 X_{3}^{2}
\end{aligned}
$$

The analysis of variance (ANOVA) of the results obtained given in Table 5 shows that the determination coefficient $\left(R^{2}\right)$ was 0.98 , this value implied that the variations of $98 \%$ for ethanolic MAE efficiency of flavonoids from $P$. thonningii leaves were attributed to the independent variables and could be explained by the defined model, and therefore only $2 \%$ of the total variations could not be explained by the model [21].

Table 5 shows that the values of $R^{2}$ and $R^{2}$ adjusted $(0.98$ and 0.97 respectively) for the model are not greatly different. Therefore, the model obtained is a good statistical model. The "Lack of fit $p$ value" of 0.9744 implies that the Lack of fit is not significant relative to pure error ( $\left.p^{>} 0.05\right)$, this confirmed the model is validated. Zhang et al. [22] defined the coefficient of variation (CV) as the ratio of the standard error of estimate to the mean value of observed response. It is a measure of reproducibility of the models, expressed in percentage.

From Table 5, the coefficient of variation (CV \%) obtained was $1.90 \%$ showing that the model was reliable and reproducible [23]. Karazhivan et al. [21] stated that a

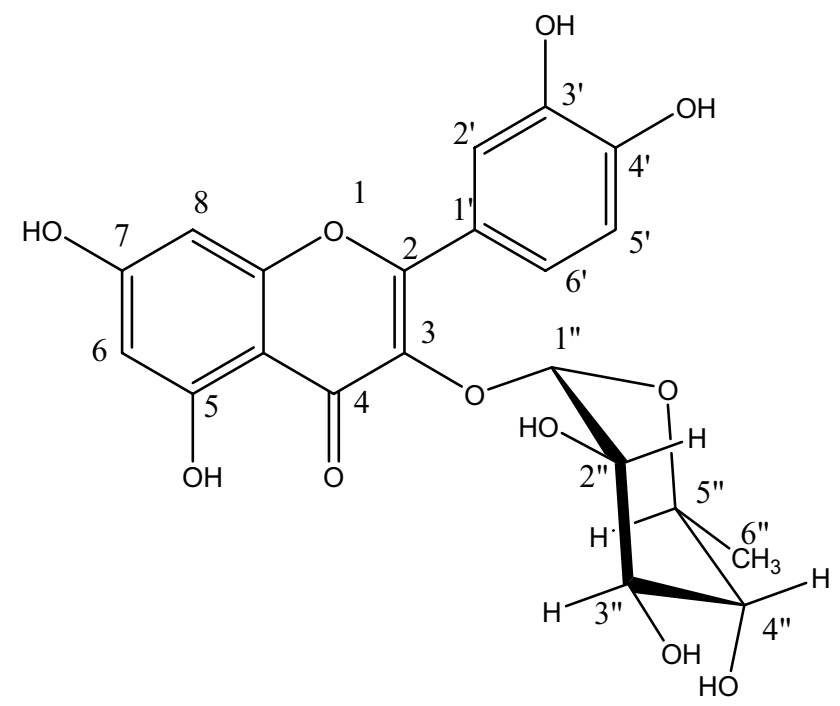

Fig. 1 Structure of isolated flavonoid quercetin-3-O-arhamnopyranoside

CV higher than $10 \%$ indicates that variation in the mean value is high and does not satisfactorily develop an adequate response model. From the value of CV obtained, the model could be validated in the prediction of ethanolic MAE of flavonoids from $P$. thonningii leaves.

\subsubsection{Analysis of percentage of factors' contributions diagram}

The effects of the independent variables and their mutual interaction on the extraction yield of flavonoids are shown in Fig. 2.

This figure shows that the linear effects of extraction time as well as the load to extract (ratio) contribute to increase the extraction of flavonoids. This was probably due to the fact that more solvent could enter cells while more active compounds could permeate into the solvent under the higher solid-liquid ratio conditions [24, 25]. With further increase in liquid-solid ratio, a decline in flavonoids yield was observed by the negative effect of quadratic effect of liquid-solid ratio.

The Fig. 2 shows that the solid-liquid ratio has highest contribution (86.4\%) in extraction of flavonoids (quercitrin) from $P$. thonningii leaves. This means that, for a given volume of extraction, the amount of flavonoids extracted increases with that of plant material in the medium due to mass transfer phenomenon. This figure also shows that there is a low contribution of linear effect of irradiation power as well as its quadratic effect $(0.27$ and $0.00 \%)$ on the ethanolic extraction of flavonoids. This phenomenon is considered to be caused by the low rate of mass transfer at low temperatures resulting to low irradiation power, which 
Fig. 2 Contribution percentage of independent variables on ethanolic MAE of flavonoids from $P$. thonningii

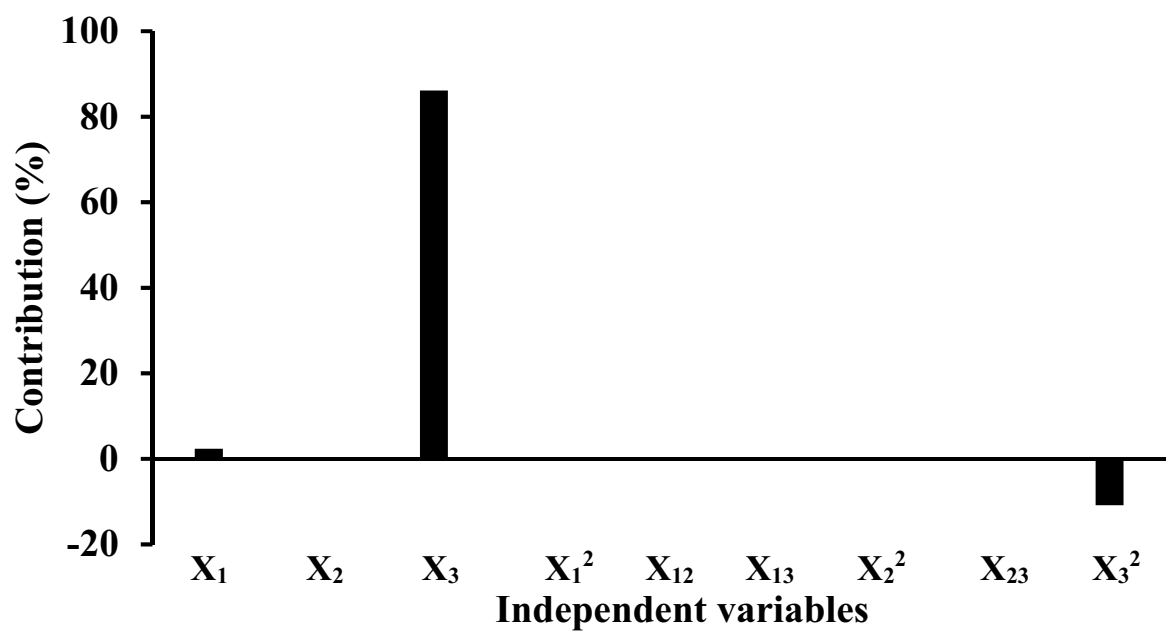

would require more time for the flavonoids to be dissolved from the raw materials into the solution. These results are similar to the research findings by Karabegovic'et al. [26]. In addition, the microwaves could accelerate cell damage and rupture by temperature rise and internal pressure increase inside the cells of plant material, which promotes the disruption of sample surface and in turns the exudation of the target substance within the cells into the surrounding solvent takes place $[24,27,28]$. At higher irradiation power however, dissolution of the compounds can reach the equilibrium in a shorter time then decreased by changes in the extraction time. This suggests that a higher irradiation power and a short extraction time are more effective in ethanolic extraction of flavonoids from $P$. thonningii using MAE. The negative effects observed at higher values of irradiation power (quadratic effect) and long period of extraction (quadratic effect) may be due to thermal degradation of the flavonoids [29]. Thus, for optimal extraction of flavonoids leaves of $P$. thonningii it would be advisable to work under moderate conditions of irradiation power in order to control this degradation of flavonoids.

\subsubsection{Optimization of the ethanolic MAE and validation of model}

The results of the optimization of the ethanolic MAE of $P$. thonningii leaves are shown in Table 6 . The predicted extraction yield of TFC was $11.44 \mathrm{mg} \mathrm{QE} / \mathrm{g}$ that was consistent with the experimental yield of $11.28 \mathrm{mg}$ QE/g. The predicted values were in close agreement with experimental values and were found to be not significantly different $(p>0.05)$ using a paired t-test $[13,30]$. It is noticed the predicted response values deviated slightly from the experimental values. The strong correlation between the real and predicted results confirmed that the response of
Table 6 Optimal conditions of ethanolic MAE of flavonoids from $P$. thonningii leaves

\begin{tabular}{|c|c|c|c|c|c|}
\hline & \multicolumn{3}{|c|}{ Actual variables } & \multicolumn{2}{|c|}{ Responses } \\
\hline & $\begin{array}{l}\text { Extrac- } \\
\text { tion time } \\
\text { (s) }\end{array}$ & $\begin{array}{l}\text { Irra- } \\
\text { diation } \\
\text { power } \\
\text { (W) }\end{array}$ & $\begin{array}{l}\text { Solid-liq- } \\
\text { uid ratio } \\
\text { (g/20 mL) }\end{array}$ & $\begin{array}{l}\text { Pre- } \\
\text { dicted }\end{array}$ & $\begin{array}{l}\text { Experi- } \\
\text { ment }\end{array}$ \\
\hline $\begin{array}{c}\text { TFC (mg } \\
\text { QE/g) }\end{array}$ & 63 & 380 & 2.01 & 11.44 & 11.28 \\
\hline
\end{tabular}

regression model was adequate to reflect the expected optimization [20].

\subsection{Optimization of hydro-ethanolic MAE conditions of flavonoids and antioxidant activities of $P$. thonningii}

\subsubsection{Modeling and fitting the model with response surface methodology (RSM)}

From a central composite design of 18 experiments, the influence of the extraction time $\left(X_{1}\right)$, the irradiation power $\left(X_{2}\right)$ and the variation of solvent concentration $\left(X_{4}\right)$ on the flavonoids extraction and antioxidant activity by MAE was evaluated during this study. The three responses of interest were total flavonoids content (TFC), DPPH antiradical activity (\%DPPH ${ }_{\text {scavenging }}$ ) and iron chelating activity (\% Iron $_{\text {chelation }}$ ). Table 7 shows the experimental design, the experimental responses, the calculated responses and the calculated residues. It appears from this table after the total flavonoid contents, the free DPPH antiradical activity $\left(\% \mathrm{DPPH}_{\text {scavenging }}\right)$ and Iron chelating activity $\left(\%\right.$ Iron $\left._{\text {chelation }}\right)$ are between 7.80 and $13.15 \mathrm{mg} \mathrm{QE} / \mathrm{g} ; 72$ and $88 \% ; 70$ and $92 \%$ respectively. The maximum values of TFC $(13.15 \mathrm{mg}$ $\mathrm{QE} / \mathrm{g}$ ) and $\% \mathrm{DPPH}_{\text {scavenging }}(88 \%)$ is obtained for experimental conditions of $X_{1}=45 \mathrm{~s}, \mathrm{X}_{2}=500 \mathrm{~W}, \mathrm{X}_{4}=30 \%$; while 
Table 7 Central composite design (CCD) and responses of MAE of flavonoids from $P$. thonningii leaves

\begin{tabular}{|c|c|c|c|c|c|c|c|c|c|}
\hline \multirow[t]{3}{*}{ Run } & \multicolumn{3}{|c|}{ Actual variables } & \multicolumn{3}{|c|}{ Experimental responses } & \multicolumn{3}{|c|}{ Calculated responses } \\
\hline & $\begin{array}{l}\text { Extrac- } \\
\text { tion time } \\
\text { (s) }\end{array}$ & $\begin{array}{l}\text { Irradiation } \\
\text { power (W) }\end{array}$ & $\begin{array}{l}\text { Solvent } \\
\text { concentra- } \\
\text { tion (\%) }\end{array}$ & $\begin{array}{l}\text { TFC (mg } \\
\text { QE/g) }\end{array}$ & $\begin{array}{l}\text { \%DPPH } \\
\text { scavenging } \\
(\%)\end{array}$ & $\begin{array}{l}\text { \%lron } \\
\text { (\%) }\end{array}$ & $\begin{array}{l}\mathrm{TFC}(\mathrm{mg} \\
\mathrm{QE} / \mathrm{g})\end{array}$ & $\begin{array}{l}\text { \%DPPH } \\
\text { scavenging } \\
(\%)\end{array}$ & $\begin{array}{l}\text { \%Iron } \\
\text { chelation } \\
\text { (\%) }\end{array}$ \\
\hline & $x_{1}$ & $x_{2}$ & $x_{3}$ & $\mathrm{Y}_{\mathrm{TFC}}$ & $Y_{D P P H}$ & $Y_{\text {Iron }}$ & $\mathrm{Y}_{\mathrm{TFC}}$ & $Y_{D P P H}$ & $Y_{\text {Iron }}$ \\
\hline 1 & 50 & 400 & 20 & 11.68 & 75.53 & 80.60 & 11.61 & 75.31 & 80.57 \\
\hline 2 & 38 & 500 & 30 & 10.29 & 73.50 & 78.65 & 10.44 & 73.95 & 78.71 \\
\hline 3 & 40 & 400 & 20 & 7.88 & 72.61 & 76.70 & 7.89 & 72.39 & 76.67 \\
\hline 4 & 45 & 360 & 30 & 10.31 & 79.00 & 79.84 & 10.44 & 79.45 & 79.90 \\
\hline 5 & 40 & 400 & 40 & 10.59 & 79.09 & 78.18 & 10.80 & 78.86 & 78.15 \\
\hline 6 & 50 & 400 & 40 & 11.34 & 82.91 & 82.98 & 11.35 & 82.68 & 82.95 \\
\hline 7 & 45 & 640 & 30 & 11.02 & 81.75 & 82.58 & 11.03 & 82.20 & 82.65 \\
\hline 8 & 40 & 600 & 20 & 9.57 & 71.75 & 70.85 & 9.49 & 71.53 & 70.82 \\
\hline 9 & 50 & 600 & 20 & 10.96 & 83.27 & 83.34 & 11.07 & 83.05 & 83.31 \\
\hline 10 & 52 & 500 & 30 & 11.95 & 84.35 & 90.87 & 11.94 & 84.79 & 90.93 \\
\hline 11 & 45 & 500 & 30 & 12.45 & 85.64 & 85.57 & 12.56 & 86.00 & 87.80 \\
\hline 12 & 45 & 500 & 30 & 13.12 & 86.95 & 88.65 & 12.56 & 86.00 & 87.80 \\
\hline 13 & 40 & 400 & 40 & 11.19 & 75.23 & 79.32 & 10.80 & 75.01 & 79.29 \\
\hline 14 & 50 & 600 & 40 & 10.67 & 87.65 & 92.72 & 10.59 & 87.43 & 92.69 \\
\hline 15 & 45 & 500 & 30 & 12.55 & 88.11 & 87.56 & 12.56 & 86.00 & 87.80 \\
\hline 16 & 45 & 500 & 44 & 12.65 & 85.76 & 86.60 & 12.80 & 86.21 & 86.66 \\
\hline 17 & 45 & 500 & 16 & 11.12 & 78.09 & 78.92 & 11.11 & 78.53 & 78.98 \\
\hline 18 & 45 & 500 & 30 & 12.25 & 84.21 & 89.56 & 12.56 & 86.00 & 87.80 \\
\hline
\end{tabular}

the maximum value in \% Iron $_{\text {chelation }}$ is obtained for $X_{1}=50$ $\mathrm{s}, \mathrm{X}_{2}=600 \mathrm{~W}$ and $\mathrm{X}_{4}=40 \%$ (Table 7). Thus, a combined optimization process to obtain desirable bioactive substances and antioxidant activity has been performed.

It was shown for the tree responses studied that all linear and quadratic parameters, extraction time $\left(X_{1}\right)$, irradiation power $\left(\mathrm{X}_{2}\right)$ and solvent concentration $\left(\mathrm{X}_{4}\right)$ were highly significant at the level of $p<0.05$. Two interactions in antioxidant activities responses $\left(\% \mathrm{DPPH}_{\text {scavenging }}\right.$ and $\%$ Iron $_{\text {chelation }}$ ) are highly significant at the level of $p<0.05$, excepting their interaction $\mathrm{X}_{1} \mathrm{X}_{4}$ (Table 8). For TFC, the interaction $\mathrm{X}_{1} \mathrm{X}_{3}$ was highly significative. Considering the significant parameters only, the final predictive equations obtained were given as below:

\subsubsection{Influence of extraction parameters on flavonoids content}

The influence of three independent variables towards total flavonoids content was reported through the significant $(p<0.05)$ coefficient of the second-order polynomial regression equation. 3D response surfaces curves in Fig. 3 demonstrated the effects of the independent variables and their mutual interactions on the TFC values. They were obtained by keeping one another variable constant. The constant was equal to the corresponding true value of zero level.

The TFC increases with time until a time of $48 \mathrm{~s}$, then remains stable (Fig. 3). It varies from $7.0 \mathrm{mg} \mathrm{QE} / \mathrm{g}$ (time

$\mathrm{Y}_{\mathrm{TFC}}=-123.82+3.625 \mathrm{X}_{1}+0.145 \mathrm{X}_{2}+0.985 \mathrm{X}_{3}-0.028 \mathrm{X}_{1}^{2}-0.016 \mathrm{X}_{1} \mathrm{X}_{3}-0.003 \mathrm{X}_{3}^{2}$

$\mathrm{Y}_{\mathrm{DPPH}}=86+3.83 \mathrm{X}_{1}+0.97 \mathrm{X}_{2}+2.71 \mathrm{X}_{3}-3.31 \mathrm{X}_{1}^{2}+2.15 \mathrm{X}_{1} \mathrm{X}_{2}-2.58 \mathrm{X}_{2}^{2}-0.75 \mathrm{X}_{2} \mathrm{X}_{3}-1.81 \mathrm{X}_{3}^{2}$

$Y_{\text {Iron }}=87.80+4.32 X_{1}+0.97 X_{2}+2.71 X_{3}-1.48 X_{1}^{2}+2.15 X_{1} X_{2}-3.26 X_{2}^{2}+1.74 X_{2} X_{3}-2.48 X_{3}^{2}$

$38 \mathrm{~s})$ to $12.0 \mathrm{mg} \mathrm{QE} / \mathrm{g}$ (time $52 \mathrm{~s}$ ). During the process, to release active compounds in the medium, the solvent of 
Table 8 Variance analysis of regression equations of TFC, $\% \mathrm{DPPH}_{\text {scavenging }}$ and \% Iron $_{\text {chelation }}$

\begin{tabular}{|c|c|c|c|c|c|}
\hline Source & Sum of square & DF & Mean square & $F$ value & $P$ value \\
\hline \multicolumn{6}{|c|}{$\operatorname{TFC}(m g Q E / g)^{a}$} \\
\hline $\mathrm{X}_{1}$ & 2.760 & 1 & 2.760 & 18.47 & 0.0127 \\
\hline$x_{2}$ & 0.405 & 1 & 0.405 & 2.71 & 0.1749 \\
\hline$x_{3}$ & 3.535 & 1 & 3.535 & 23.66 & 0.0083 \\
\hline $\mathrm{X}_{1}^{2}$ & 3.646 & 1 & 3.646 & 24.40 & 0.0078 \\
\hline $\mathrm{X}_{1} \mathrm{X}_{2}$ & 1.615 & 1 & 1.615 & 10.81 & 0.0303 \\
\hline$x_{1} x_{3}$ & 3.712 & 1 & 3.712 & 24.84 & 0.0076 \\
\hline $\mathrm{X}_{2}^{2}$ & 6.477 & 1 & 6.477 & 43.35 & 0.0028 \\
\hline$x_{2} X_{3}$ & 0.018 & 1 & 0.018 & 0.12 & 0.7451 \\
\hline$X_{3}^{2}$ & 0.707 & 1 & 0.707 & 4.73 & 0.0952 \\
\hline Pure error & 0.60 & 3 & 0.15 & & \\
\hline Lack of fit & 0.11 & 5 & 0.03 & 0.20 & 1.0000 \\
\hline CV (\%) & 4.58 & & & & \\
\hline Total & 27.17 & 17 & & & \\
\hline \multicolumn{6}{|c|}{$\% D P P H_{\text {scavenging }}(\%)^{b}$} \\
\hline $\mathrm{X}_{1}$ & 176.46 & 1 & 176.46 & 62.42 & 0.0042 \\
\hline$x_{2}$ & 11.327 & 1 & 11.327 & 4.01 & 0.1391 \\
\hline$x_{3}$ & 88.350 & 1 & 88.350 & 31.25 & 0.0113 \\
\hline $\mathrm{X}_{1}^{2}$ & 87.869 & 1 & 87.869 & 31.08 & 0.0114 \\
\hline $\mathrm{X}_{1} \mathrm{X}_{2}$ & 36.98 & 1 & 36.98 & 13.08 & 0.0363 \\
\hline$x_{1} x_{3}$ & 0.405 & 1 & 0.405 & 0.14 & 0.7303 \\
\hline$x_{2}^{2}$ & 53.629 & 1 & 53.629 & 18.97 & 0.0224 \\
\hline$x_{2} X_{3}$ & 4.5 & 1 & 4.5 & 1.59 & 0.2963 \\
\hline$X_{3}^{2}$ & 26.329 & 1 & 26.329 & 9.31 & 0.0554 \\
\hline Pure error & 8.481 & 3 & 2.827 & & \\
\hline Lack of fit & 1.81 & 5 & 0.361 & 0.13 & 0.9753 \\
\hline CV (\%) & 2.05 & & & & \\
\hline Total & 496.14 & 17 & & & \\
\hline \multicolumn{6}{|c|}{$\%_{\text {Iron }}$ chelation $(\%)^{c}$} \\
\hline $\mathrm{X}_{1}$ & 224.24 & 1 & 224.24 & 76.05 & 0.0032 \\
\hline$x_{2}$ & 11.327 & 1 & 11.327 & 3.84 & 0.1448 \\
\hline$X_{3}$ & 88.349 & 1 & 88.349 & 29.96 & 0.0120 \\
\hline $\mathrm{X}_{1}^{2}$ & 17.741 & 1 & 17.741 & 6.02 & 0.0914 \\
\hline $\mathrm{X}_{1} \mathrm{X}_{2}$ & 36.98 & 1 & 36.98 & 12.54 & 0.0383 \\
\hline $\mathrm{X}_{1} \mathrm{X}_{3}$ & 0.405 & 1 & 0.405 & 0.14 & 0.7355 \\
\hline $\mathrm{X}_{2}^{2}$ & 85.238 & 1 & 85.238 & 28.91 & 0.0126 \\
\hline $\mathrm{X}_{2} \mathrm{X}_{3}$ & 24.499 & 1 & 24.499 & 8.31 & 0.0634 \\
\hline$X_{3}^{2}$ & 49.567 & 1 & 49.567 & 16.81 & 0.0262 \\
\hline Pure error & 8.8457 & 3 & 2.94 & & \\
\hline Lack of fit & 0.033 & 5 & 0.0067 & 0.00 & 1.0000 \\
\hline CV (\%) & 1.26 & & & & \\
\hline Total & 547.237 & 17 & & & \\
\hline
\end{tabular}

${ }^{a}$ The coefficient of determination $\left(R^{2}\right)$ and adjusted $R^{2}$ of the model was $97.34 \%$ and $94.40 \%$

${ }^{b}$ The coefficient of determination $\left(R^{2}\right)$ and adjusted $R^{2}$ of the model was $97.93 \%$ and $95.59 \%$

'The coefficient of determination $\left(R^{2}\right)$ and adjusted $R^{2}$ of the model was $98.37 \%$ and $96.55 \%$ extraction (ethanol) takes a minimum time to enter the powder of the leaves, dissolves the active substances (flavonoids) which subsequently diffuse into the medium (solvent). The low values of extraction time indicate that the extraction of compounds could be facilitated by radiation, thus prolonged exposure leads to destruction of the structures of the compounds by heating, corresponding to the negative influence of the quadratic effect of the time observed on the extraction of TFC (Fig. 3). These results are in agreement with those of Hismath et al. [31] who observed that the quadratic effect of time has a negative influence on the extraction of phenolic compounds from the powder of Azadirachta indica leaves.

Concerning the effect of the irradiation power on the extraction of flavonoids, their content increases exponentially with the power then decreases. This content varies from 6.0 (at $360 \mathrm{~W}$ ) to 11.0 (at $550 \mathrm{~W}$ ) $\mathrm{mg} \mathrm{QE} / \mathrm{g}$, then decreases to $10.0 \mathrm{mg} \mathrm{QE} / \mathrm{g}$ for an irradiation power of $600 \mathrm{~W}$ (Fig. 3b). An increase in the irradiation power of microwave causes an increase in the heating temperature of the extraction system. As shown in Fig. 3b, the quadratic effects of irradiation power and interaction between irradiation power-extraction time tend to decrease flavonoids extraction. According to Gan and Latiff [32], high temperature could cause softening of plant tissue, disruption of phenolics compound interactions with proteins or polysaccharides, and increase their solubility and improve their diffusion rate. Once these compounds are extracted, a fairly long exposure to the oven waves would lead to a destruction of the latter under the effect of heat, hence the negative interaction between extraction time- irradiation power (Fig. 3).

Indeed, for prolonged exposure in heating waves, flavonoids are sensitive to degradation because of their hydroxyl groups and ketone, as well as their double unsaturated liaisons [33-35]. It is therefore important to find the optimal conditions for MAE of these flavonoids in order to avoid their possible degradation.

The TFC increases exponentially with the increase in the polarity of solvent (Fig. 3a). The addition of water in ethanol increases the polarity of the medium, the solubility of phenolic compounds and thus facilitates the extraction of these. The ethanol:water system obtained is therefore capable of extracting highly polar, less polar compounds, as well as those of moderate polarity [36].

\subsubsection{Influence of extraction parameters on antioxidant activities (\%DPPH scavenging and $\%$ Iron $_{\text {chelation }}$ )}

The influence of irradiation power and extraction time on the free DPPH antiradical activity is shown in Fig. 4. This activity evolves in a hyperbolic way with both the irradiation power and the extraction time. 

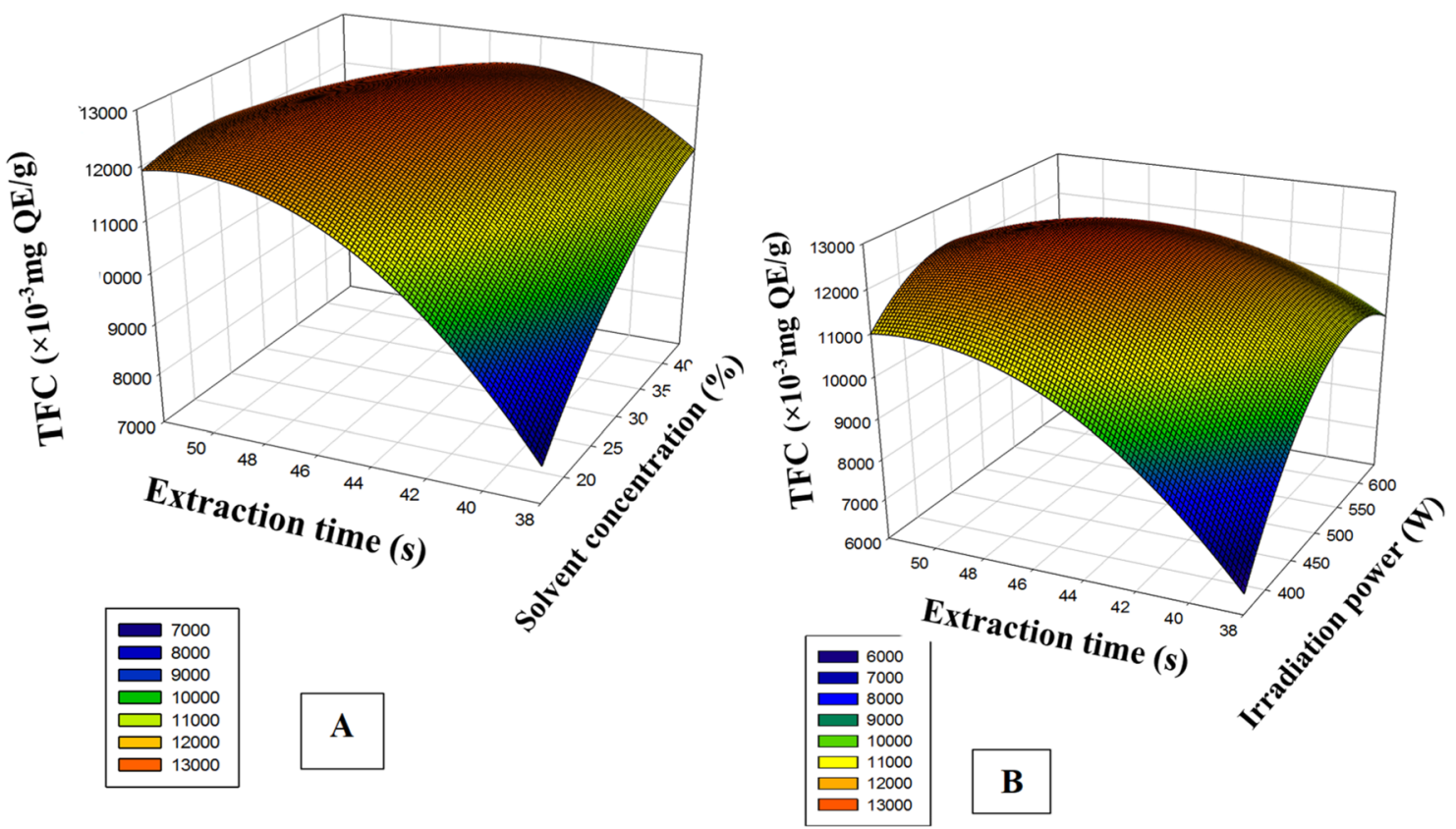

Fig. 3 Response surface analysis for the total flavonoids yield from P. thonningii leaves residues with MAE with respect to extraction time and solvent concentration (a) and extraction time and irradiation power (b)
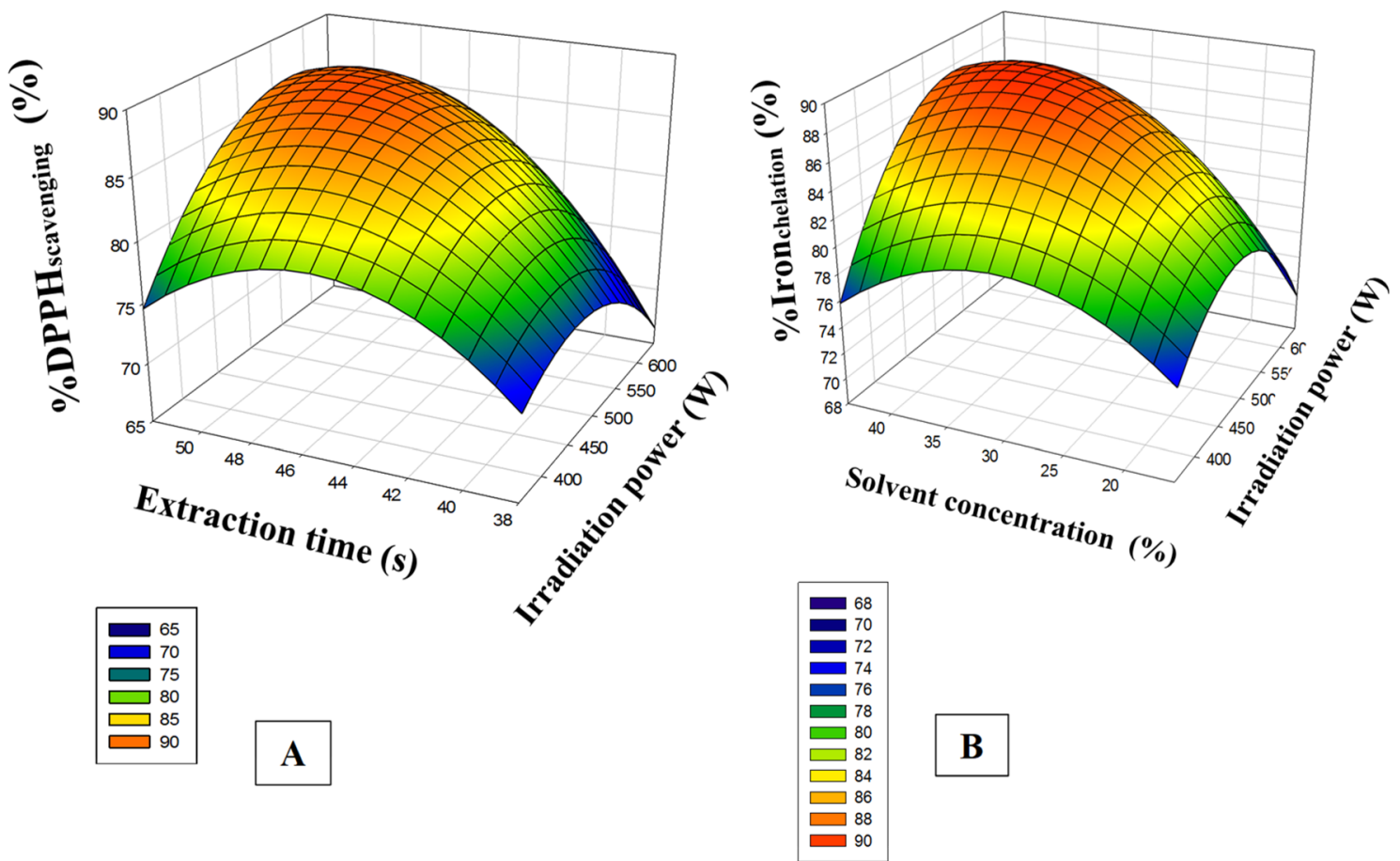

\section{B}

Fig. 4 Response surface analysis for the antioxidant activities from $P$. thonningii leaves with MAE with respect to extraction time and irradiation power (a); irradiation power and solvent concentration (b)

The antiradical activity increases with the extraction time and the irradiation power until reaching a maximum, then decreases. An increase in activity of $65-80 \%$ is observed when the time goes from 38 to $45 \mathrm{~s}$. An increase of $65-75 \%$ is observed for the passage of the irradiation power from 360 to $500 \mathrm{~W}$ taken individually. However, a 
combined effect of irradiation power and extraction time helps to maximize antiradical activity up to $87 \%$ for a power of $550 \mathrm{~W}$ and a time of $50 \mathrm{~s}$ (Fig. 4a).

The influence of the variation of the polarity of solvent and the irradiation power on the iron chelating activity is presented by the response surface (Fig. 4b). The chelating activity of iron increases with the concentration of water in the extraction medium. An increase in activity of $65-80 \%$ is observed when the water content in solvent increases from 20 to $35 \%$. The extraction of the active substances is therefore favored in a hydroethanolic medium, the $100 \%$ $(\mathrm{v} / \mathrm{v})$ ethanol would not be effective enough for the extraction of phenolic compounds. Prasad et al. [36] show that $68 \%(\mathrm{v} / \mathrm{v})$ ethanol is optimum for optimal total antioxidant activity. However, a reduction in activity when the water concentration is greater than $35 \%(\mathrm{v} / \mathrm{v})$ (as solvent) is observed (Fig. 4b). This could be explained by the fact that the solubility of flavonoids decreases with the concentration of water in the medium, for high water content we would witness the extraction of other compounds with low chelating activity.

\subsubsection{Optima of flavonoids MAE and antioxidant activity of $P$. thonningii}

3.2.4.1 Graphical optimization: optimal zone Using the polynomial models presented above, the contour lines for each response were made as a function of the extraction time and the change in the polarity of the solvent, the irradiation power was kept constant. Before optimization, the limits were fixed according to the influence study of the factors (response surface curves). These are the maximum values obtained according to the effect of individual factors:

- Total flavonoids content $\geq 12.00 \mathrm{mg} \mathrm{QE} / \mathrm{g}$

- Free DPPH Antiradical activity $\geq 80 \%$

- Iron complexing activity $\geq 80 \%$.

Graphical optimization was made to have optimal conditions for the extraction of flavonoids, the free DPPH antiradical activity and the iron chelating activity. To do this, the contour curves obtained after modeling the different indices were superimposed, and the resulting graph shows the shaded area that respects the limits set for a better antioxidant activity of the microwave extracts of $P$. thonningii leaves (TFC $\geq 12.00 \mathrm{mg} \mathrm{QE} / \mathrm{g}$, $\% \mathrm{DPPH}_{\text {scavenging }} \geq 80 \%$ and $\%$ Iron $_{\text {chelation }} \geq 80 \%$ ). Any combination possible in this shaded area will result in extracts with high antioxidant activity (Fig. 5). To obtain an extract of optimal antioxidant activity, it is important to extract the leaves of $P$. thonningii under the following conditions: irradiation power of $500 \mathrm{~W}$, extraction time between 43 and $52 \mathrm{~s}$ with an ethanol concentration from 55 to $75 \%$ $(\mathrm{v} / \mathrm{v})$ as solvent.

3.2.4.2 Multi-response optimization A multi-response optimization was performed for total flavonoids content, antioxidant activities (DPPH antiradical activity and iron chelating activity). The combination of the different factors is shown in Table 9. For this combination, the calculated optimal values are: $\mathrm{TFC}=12.65 \mathrm{mg} \mathrm{QE} / \mathrm{g}$; $\% \mathrm{DPPH}_{\text {scavenging }}=88.55 \%$ and $\%$ Iron $_{\text {chelation }}=94.04 \%$.

The optimal conditions for the combined responses belong to the optimum domain predicted by the superposition of the contour plot. The combined optima were checked and the TFC values $=12.77 \mathrm{mg} \mathrm{QE} / \mathrm{g}$, the $\% \mathrm{DPPH}_{\text {scavenging }}=91.27 \%$ and the $\%$ Iron $_{\text {chelation }}$ of $88.11 \%$ were obtained compared to the theoretical values $\left(\mathrm{TFC}=12.46 \mathrm{mg} \mathrm{QE} / \mathrm{g}, \% \mathrm{DPPH}_{\text {scavenging }}=91.4 \%\right.$ and $\%$ Iron $\left._{\text {chelation }}=88.11 \%\right)$.

\subsection{HPLC chromatographic profile of extracts at different optimal conditions}

The following figure (Fig. 6) shows the profile of extracts from leaves of $P$. thonningii optimized with ethanol and ethanol-water by MAE and by maceration. On this profile, the characteristic quercetin-3-O-rhamnoside (quercitrin) peak is identified at retention time of $15 \mathrm{~min}$. The quantitation analysis was done by normalized area percentage methods, in which the area percentage of each peak is reported and the total area percentage equals $100 \%$. The calculation of the percentages of characteristic quercitrin peak from the individual quercitrin peak areas and in relation to the total area is shown in the Table 10.

It is shown from Table 10 that for the same analysis conditions, the extract optimized with the ethanol-water solvent system has a greater total surface $\left(69.35 \times 10^{6}\right)$. Optimization of ethanolic extraction has helped to maximize quercetin-3-O-rhamnoside extraction. However, the second optimization (hydro-ethanolic extraction) has helped to further maximize the extraction of this active compound quercetin-3-O-rhamnoside. Adding water to ethanol is necessary to promote the solubilization of flavonoids and thus facilitate their extraction [37]. Furthermore, comparing the different total surfaces, it is noted the extract obtained by ethanolic maceration has the smallest total surface $\left(3.87 \times 10^{6}\right)$. In fact, heating due to the action of waves would help to maximize the extraction process of the active substances of $P$. thonningii.

\subsection{Antioxidant activities of optimized extracts}

The antioxidant activities of the various extracts obtained are recorded in Table 11. It can be seen from this table that 

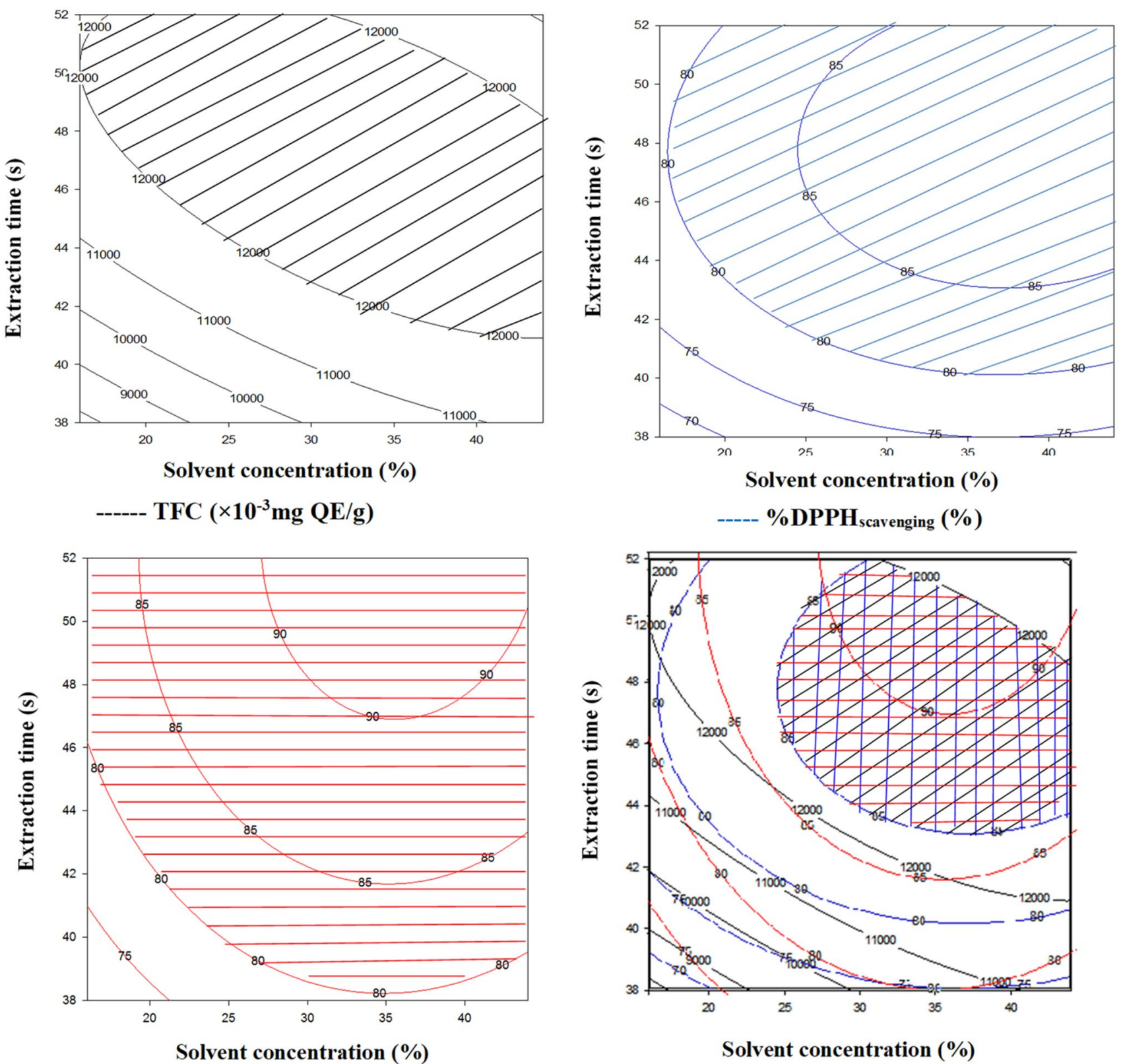

----- \%Iron chelation ( $\%)$

Fig. 5 Optimization by compromise area of flavonoids extraction and DPPH scavenging and iron chelating activities

Table 9 Optimal conditions of MAE of TFC, \%DPPH ${ }_{\text {scavenging }}$ and $\%$ Iron $_{\text {chelation }}$

\begin{tabular}{llll}
\hline & \multicolumn{2}{l}{ Actual variables } & \\
\cline { 2 - 4 } & $\begin{array}{l}\text { Extraction time } \\
(\mathrm{s})\end{array}$ & $\begin{array}{l}\text { Irradiation } \\
\text { power (W) }\end{array}$ & $\begin{array}{l}\text { Solvent con- } \\
\text { centration (\%) }\end{array}$ \\
\hline $\begin{array}{c}\text { Combined } \\
\text { optimum }\end{array}$ & 49 & 520 & 33 \\
\hline
\end{tabular}

the microwaves treatment contributes to increasing the extraction of the antioxidant compounds of $P$. thonningii. With regard to the iron chelating activity, it is found that the complexing activity of the optimized extracts of $P$. thonningii is twice the standard (ascorbic acid) on the one hand and at a dose 3 times lower than that of the extract obtained by maceration. This shows the interest of a sequential optimization by microwaves, because this process contributes to enrich the extracts in active compounds quercitrin. 

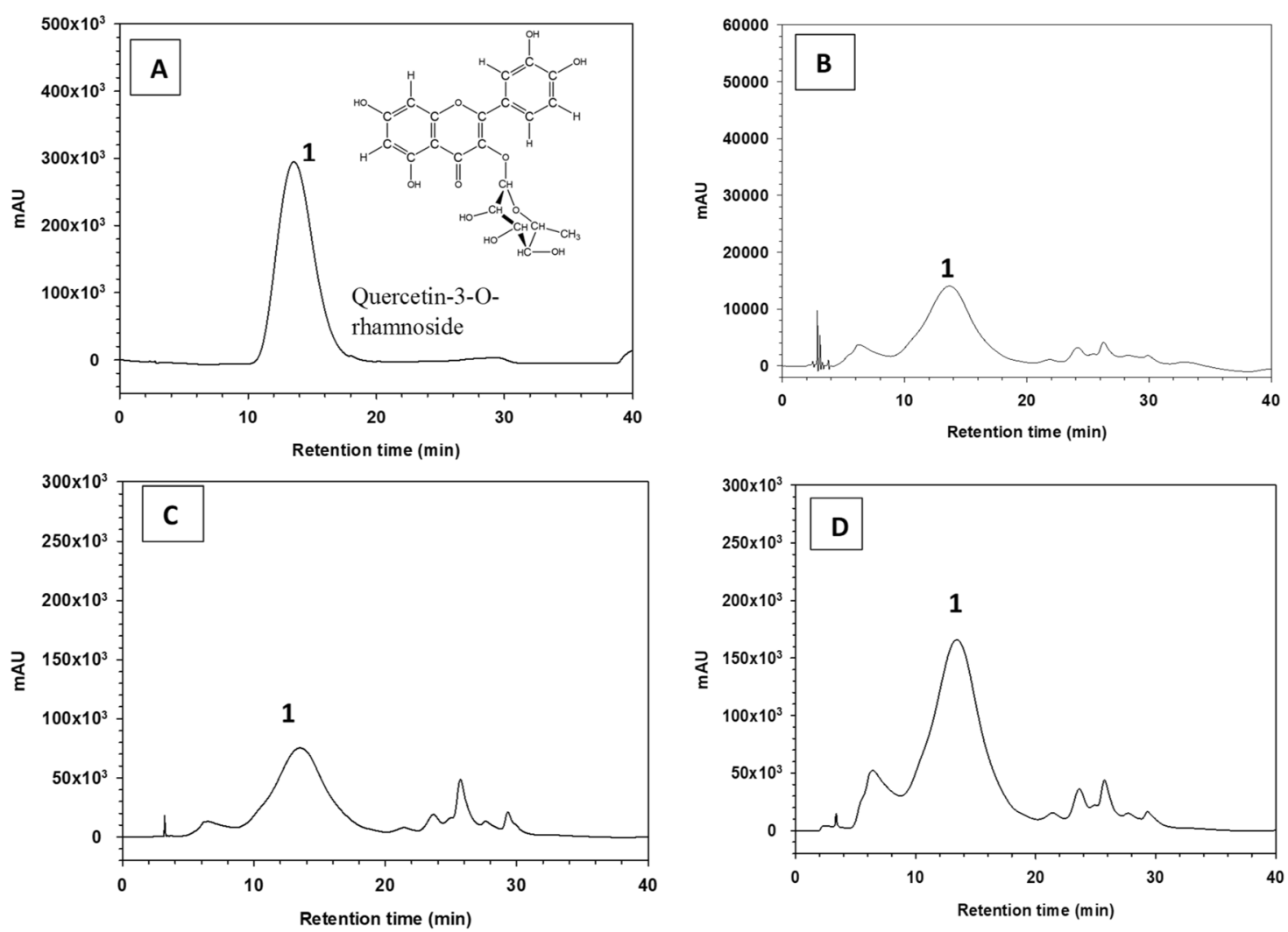

Fig. 6 HPLC Chromatograms at $254 \mathrm{~nm}$ of quercetin-3-O-rhamnoside (a) and extracts obtained by maceration (b), optimization with etha$\mathrm{nol}(\mathbf{c})$ and optimization with ethanol-water (d)

Table 10 Relative percentage of characteristic peaks and total areas for the different extracts obtained from $P$. thonningii by maceration and MAE

Table $11 \mathrm{IC}_{50}(\mu \mathrm{g} / \mathrm{mL})$ of the optimized extracts obtained by maceration and sequential optimization by microwaves

\begin{tabular}{lcll}
\hline & Maceration & $\begin{array}{l}\text { Ethanol optimi- } \\
\text { zation }\end{array}$ & $\begin{array}{l}\text { Ethanol-water } \\
\text { optimization }\end{array}$ \\
\hline Retention time $(\mathrm{min})$ & 13.66 & 13.49 & 13.42 \\
Surface of quercitrin peak $\left(\times 10^{6} \mathrm{mAU}{ }^{*} \mathrm{~min}\right)$ & 3.21 & 18.3 & 51.46 \\
Relative percentage of quercitrin in extract $(\%)$ & 82.83 & 71.06 & 74.17 \\
Total peak area of extract $\left(\times 10^{6} \mathrm{mAU}\right.$ min) & 3.87 & 25.75 & 69.35 \\
\hline
\end{tabular}

\begin{tabular}{llllll}
\hline & Extracts & & & Standards \\
\cline { 2 - 5 } & $\begin{array}{l}\text { Ethanolic } \\
\text { maceration }\end{array}$ & $\begin{array}{l}\text { Ethanolic MAE } \\
\text { optimization }\end{array}$ & $\begin{array}{l}\text { Optimization } \\
\text { ethanol:water }\end{array}$ & $\begin{array}{l}\text { Combination of } \\
\text { MAE extracts }\end{array}$ & Quercitrin \\
\hline $\mathrm{DPPH}_{\text {scavenging }}$ & 98.9 & 77.0 & 74.07 & 63.49 & 25.7 \\
Iron $_{\text {chelation }}$ & 35.5 & 21.1 & 17.08 & 15.05 & 11.3 \\
\hline
\end{tabular}

\subsection{Morphology of P. thonningii cake obtained by scanning electron microscopy (SEM)}

The microscopic observation (Fig. 7.) of the cakes obtained by conventional method of extraction, MAE with ethanol and MAE with ethanol-water, showed that compared to the powder of $P$. thonningii leaves not treated with microwaves, the extraction maceration leads to changes in the cells morphology, but the damage is different depending on the extraction method applied.

The high pressure and temperature involved in the MAE process will destroy the cell walls of the plant matrix, 


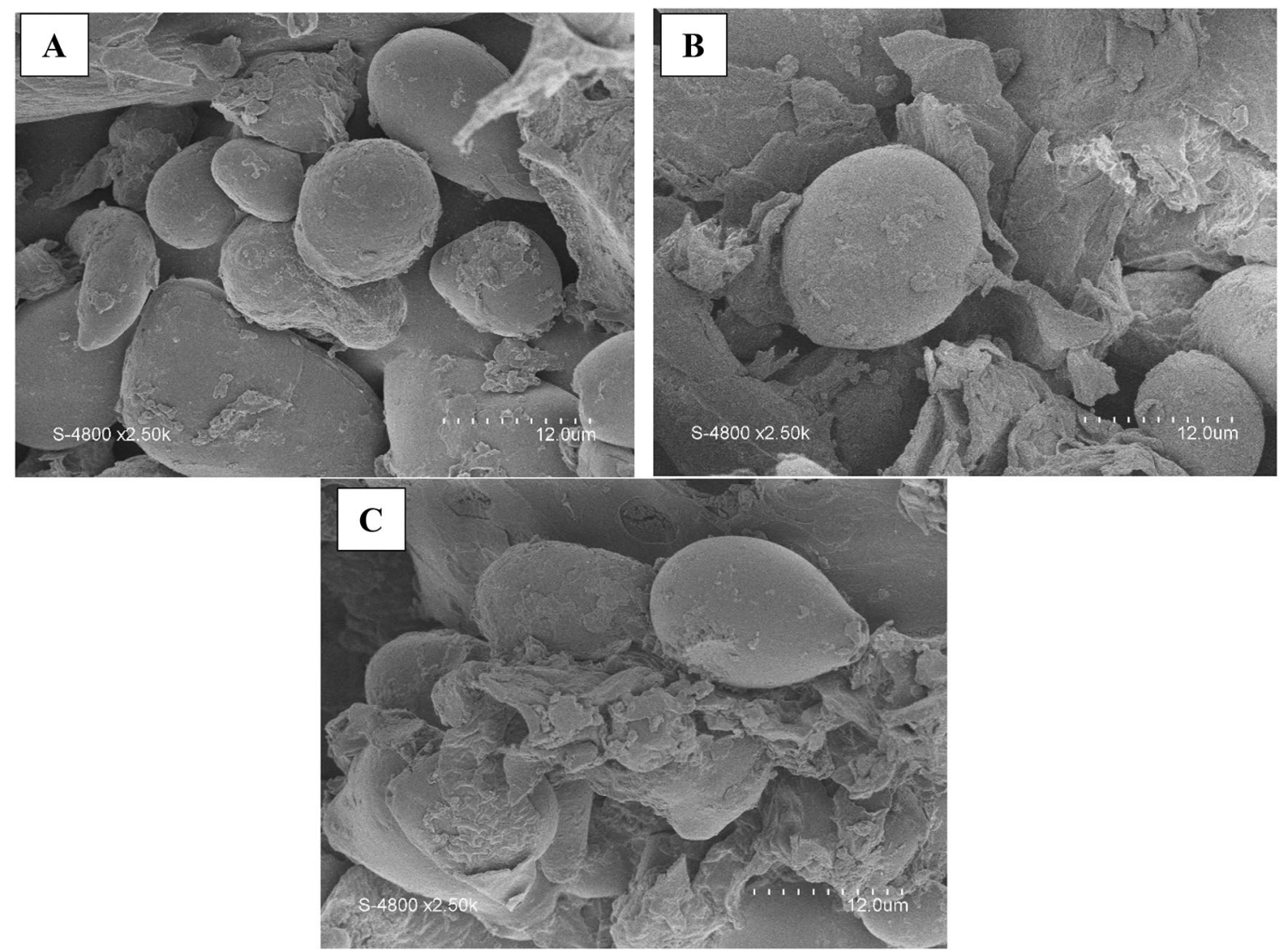

Fig. 7 Scanning electron microscopic images $(\times 2500)$ of untreated $P$. thonningi leaves $(\mathbf{a})$, residues in the extraction of conventional-solvent extracted leaves (b), and microwave-assisted extracted (MAE) leaves (c)

which facilitates the release of extractable compounds and improves mass transport by disrupting the cell walls of the product and its content can be released in the medium (C) [36]. Indeed, in MAE process, the microwaves dehydrate the cellulose and reduce its mechanical resistance, which allows easy penetration of the solvent into the cell channels [13]. The exposure of plant material to microwave has resulted in the increase of contact of solute with solvent through partial destruction of the solid phase and generation of cracks.

\section{Conclusion}

The objective of this study was to optimize the microwave assisted extraction (MAE) of quercetin-3-O-rhamnoside from $P$. thonningii leaves. Ethanol was used to a first optimization of this compound with antioxidant properties. Thereafter, on the residue obtained after the first optimization, the ethanol:water system was subsequently used for maximizing this extraction by optimization using the response surface methodology (RSM). The optimal conditions of extraction of active compound with maximum antioxidant activities are successively $63 \mathrm{~s}, 380 \mathrm{~W}$ and solid-liquid ratio of $1 / 10(\mathrm{w} / \mathrm{v})$ for the first extraction, and $49 \mathrm{~s}, 520 \mathrm{~W}$ and ethanol concentration of $67 \%$ as solvent for extraction from the residue. It is found that the antioxidant activity (complexing activity) of the optimized extracts of $P$. thonningii is twice the value of standard on the one hand and at a dose 3 times lower than that of the extract obtained by maceration.

Acknowledgements The authors thank the Institut Européen des Membranes of University of Montpellier, France for collaboration. Particularly Mr. Didier COT for his help in carrying out the Scanning electron microscopic assay.

Availability of data and materials Research data have been provided in the manuscript.

\section{Compliance with ethical standards}

Conflict of interest The authors declare that they have no competing interests. 


\section{References}

1. Burkill HM (1995) The useful plants of west Tropical Africa, 2nd edn. Royal Botanic Garden Kew, Richmond, pp 146-149

2. Dasofunjo K, Nwodo OFC, Johnson JT, Ukpanukpong RU, Ugwu MN, Ayo VI (2013) Phytochemical screening and effect of ethanolic leaf extract of Piliostigma thonningii on serum lipid profile of male albino rats. J Nat Prod Plant Resour 3:5-9

3. Ibewuike JC, Ogundani AO, Ogungbanla OF, Martin MT, Gallard J-F, Bohlin L, Pais M (1996) Piliostigmin, A2-phenoxychrome and C-methyl flavonol from Piliostigma thonningii. Phytochemistry 43:687-690

4. Ozolua Rl, Alonge P, Igbe I (2009) Effects of leaf extracts of Piliostigma thonningii Schum. on aortic ring contractility and bleeding time in rats. J Herbs Spices Med Plants 15:326-333

5. Nugroho A, Hesty H, Jae SC, Hee-Juhn P (2017) Identification and quantification of flavonoids in Carica papaya leaf and peroxynitritescavenging activity. Asian Pac J Trop Biomed 7(3):208-213

6. Mutalib AA, Ashwell RN, Kannan RRR, Van Johannes S (2013) Antimicrobial and selected in vitro enzyme inhibitory effects of leaf extracts, flavonols and indole alkaloids isolated from Croton menyharthii. Molecules 18:12633-12644

7. Luthria DL (2008) Influence of experimental conditions on the extraction of phenolic compounds from parsley (Petroselinum crispum) flakes using a pressurized liquid extractor. Food Chem 107(2):745-752

8. Spigno G. \& De Faveri, Microwave-assisted extraction of tea phenols: A phenomenological study. Journal of Food Engineering, 93(2) (2009) 210-217

9. Jerman T, Trebše P, Mozetic BV (2010) Ultrasound-assisted solid liquid extraction (USLE) of olive fruit (Olea europaea) phenolic compounds. Food Chem 123(1):175-182

10. Jun X, Deji S, Ye L, Rui Z (2011) Comparison of in vitro antioxidant activities and bioactive components of green tea extracts by different extraction methods. Int J Pharm 408(1):97-101

11. Camel V (2000) Microwave-assisted solvent extraction of environmental samples. TrAC Trends Anal Chem 19(4):229-248

12. Pérez-Serradilla J, Luque de Castro M (2011) Microwave-assisted extraction of phenolic compounds from wine lees and spraydrying of the extract. Food Chem 124(4):1652-1659

13. Dahmoune F, Nayak B, Moussi K, Remini H, Madani K (2015) Optimization of microwave- assisted extraction of polyphenols from Myrtus communis L leaves. Food Chem 166:585-595

14. Gallo M, Ferracane R, Graziani G, Ritieni A, Fogliano V (2010) Microwave assisted extraction of phenolic compounds from four different spices. Molecules 15(9):6365-6374

15. Burkert R, Helberg HW, Von Schiitz JU (1993) Longitudinal and transverse conductivity in (2,5-Me2-DCNQI) Cu fibres. Synth Met $56: 2519-2524$

16. Jassie LR, Kierstead RT, Hasty E (1997) Microwave-enhanced chemistry. In: Kingston HM, Haswell SJ (eds) Fundamentals, sample preparation and applications. American Chemical Society, Washington, p 569

17. Raner KD, Strauss CR, Vyskoc F, Mokbel L (1993) A comparison of reaction kinetics observed under microwave irradiation and conventional heating. J Org Chem 58:950-995

18. Cornard JP, Merlin JC (2002) Spectroscopic and structural study of complexes of quercetin with $\mathrm{Al}(\mathrm{III})$. J Inorg Biochem 92(1):19-27

19. Dinis TCP, Madeira VMC, Almeida LM (1994) Action of phenolic derivatives (acetaminophen, salicylate and 5-aminosalicylate) as inhibitors of membrane lipid peroxidation and peroxyl radical scavengers. Arch Biochem Biophys 315(1):161-169
20. Zhang G, Hu M, He L, Fu P, Wang L, Zhou J (2013) Optimization of microwave-assisted enzymatic extraction of polyphenols from waste peanut shells and evaluation of its antioxidant and antibacterial activities in vitro. Food Bioprod Process 91(2):158-168

21. Karazhiyan H, Razavi S, Phillips GO (2011) Extraction optimization of a hydrocolloid extract from cress seed (Lepidium sativum) using response surface methodology. Food Hydrocoll 25(5):915-920

22. Zhang Y, Liu Z, Li Y, Chi R (2014) Optimization of ionic liquidbased microwave-assisted extraction of isoflavones from Radix puerariae by response surface methodology. Sep Purif Technol 129:71-79

23. Chen W, Wang W, Zhang H, Huang Q (2012) Optimization of ultrasonic assisted extraction of water-soluble polysaccharides from Boletus edulis mycelia using response surface methodology. Carbohydr Polym 87(1):614-619

24. Prasad NK, Chun Y, En Y, Zhao M, Jiang Y (2009) Effects of high pressure on the extraction yield, total phenolic content and antioxidant activity of long and fruit pericarp. Innov Food Sci Emerg Technol 10:155-159

25. Zheng X, Wang X, Lan Y, Shi J, Xue SJ, Liu C (2009) Application of response surface methodology to optimize microwave-assisted extraction of silymarin from milk thistle seeds. Sep Purif Technol 70:34-40

26. Karabegovic IT, Stojičević SS, Veličković DT, Nikolić NČ, Lazi ML (2013) Optimization of microwave-assisted extraction and characterization of phenolic compounds in cherry laurel (Prunus laurocerasus) leaves. Sep Purif Technol 120:429-436

27. Chirinos R, Rogez H, Campos D, Pedreschi R, Larondelle Y (2007) Optimization of extraction conditions of antioxidant phenolic compounds from mashua (Tropaeolum tuberosum Ruíz \& Pavón) tubers. Sep Purif Technol 55:217-225

28. Xia E-Q, Cui B, Xu X-R, Song Y, Ai X-X, Li H-B (2011) Microwaveassisted extraction of oxymatrine from Sophora flavescens. Molecules 16:7391-7400

29. Meneses NGT, Martins S, Teixeira JA, Mussatto SI (2013) Influence of extraction solvents on the recovery of antioxidant phenolic compounds from brewer's spent grains. Sep Purif Technol 108:152-158

30. Hossain MB, Brunton NP, Patras A, Tiwari B, Odonnell C, MartinDiana AB (2012) Optimization of ultrasound assisted extraction of antioxidant compounds from marjoram (Origanum majorana L.) using response surface methodology. Ultrason Sonochem 19(3):582-590

31. Hismath I, WanAida WM, Ho CW (2011) Optimization of extraction conditions for phenolic compounds from neem (Azadirachta indica) leaves. Int Food Res J 18(3):931-939

32. Gan CY, Latiff AA (2011) Optimisation of the solvent extraction of bioactive compounds from Parkia speciosa pod using response surface methodology. Food Chem 124:1277-1283

33. Buchner N, Krumbein A, Rohn S, Kroh LW (2006) Effect of thermal processing on the flavonols rutin and quercetin. Rapid Communun Mass Spectrom 20:3229-3235

34. Ioannou I, Hafsa I, Hamdi S, Charbonnel C, Ghoul M (2012) Review of the effect of food processing and formulation on flavonols and anthocyanin behavior. J Food Eng 111:208-217

35. Quiao L, Yujing S, Rongrong C, Yu F, Wenjuan Z, Xin L, Jianchu C, Yan S, Xingqian Y (2014) Sonochemical effects on 14 flavonoids common in citrus: relation to stability. PLoS ONE 9:e87766

36. Prasad KN, Fouad AH, Bao Y, Kin WK, Ramakrishnan NR, Azrina A, Ismail A (2011) Response surface optimization for the extraction of phenolic compounds and antioxidant capacities of underutilised Mangifera pajang Kosterm. Peels. Food Chem 128:1121-1127 
37. Zhang Z-S, Li D, Wang LJ, Ozkan N, Chen XD, Mao Z-H, Yang H-Z (2007) Optimisation of ethanol-water extraction of lignans from faxseed. J Sep Purif Technol 57:17-24
Publisher's Note Springer Nature remains neutral with regard to jurisdictional claims in published maps and institutional affiliations. 